\title{
A Review on Potential Biotechnological applications of Microalgae
}

\author{
Santhosh Sigamani ${ }^{1}$, Dhandapani Ramamurthy ${ }^{2}$, Hemalatha Natarajan $^{1 *}$ \\ ${ }^{1}$ Applied Microbiology Laboratory, Department of Microbiology, Periyar University, Salem-636011, Tamilnadu, India. \\ ${ }^{2}$ Fermentation Technology Laboratory, Department of Microbiology, Periyar University, Salem-636011, Tamilnadu, India.
}

\begin{tabular}{l} 
ARTICLE INFO \\
\hline Article history: \\
Received on: $17 / 04 / 2016$ \\
Revised on: 09/05/2016 \\
Accepted on: $17 / 06 / 2016$ \\
Available online: $30 / 08 / 2016$ \\
\hline Key words: \\
Microalgae, metabolites, \\
extraction, compound, toxins.
\end{tabular}

\begin{abstract}
Microalgae are microscopic photosynthetic organisms that are found in both marine and freshwater environments. Microalgae belong to the fastest growing photosynthetic organisms since their cell doubling time can be as little as a few hours. They are highly efficient biological approach for converting $\mathrm{CO}_{2}$ and nutrients to biomass. Eukaryotic microalgae and cyanobacteria have recently reemerged as promising organisms in the effort to develop sustainable options for production of food and fuel. Marine microalgae constitute a natural source of a variety of drugs for pharmaceutical, food and cosmetic applications-which encompass carotenoids, among others. The bioactive compounds derived from microalgae have anticancer, anti-inflammatory, antimicrobial, and antioxidant activities. The aim of this review is to discuss bioactive metabolites produced by microalgae for possible applications in the Biotechnological fields.
\end{abstract}

\section{INTRODUCTION}

Microalgae are marine photosynthetic microorganisms which have the ability to transform carbon dioxide into biochemicals that can be further processed into biofuels, food, feed and high value bioactive compounds (Walker et al., 2005). Microalgae are present in both aquatic as well as terrestrial environment, signifying a large variety of species living in a wide range of habitats. It is predicted that more than 50,000 species of microalgae prevails, but only around 30,000, have been studied and analyzed (Richmond, 2004). The major requirement for growth of algae is sunlight, water, nutrients and arable land. Micro algae have the ability to fix $\mathrm{CO}_{2}$ using solar energy with efficiency 10 times more than that of the terrestrial plants. Algae are more proficient at utilizing sunlight than terrestrial plants, and they consume harmful pollutants, resource requirements is very less and do not compete with food or agriculture for precious resources (Brennan and Owened, 2010). With regard to biofuels, the biomass obtained from algae is considered likely to be one of the most important sources of renewable energies in the

\footnotetext{
* Corresponding Author

Email:aarthihema2004@yahoo.com
}

upcoming future (Demirbas, 2010). Biodiesel production from microalgae is a proven technology, it still overcomes numerous technical and economical constraints that are need to be mentioned (Pienkos and Darzins, 2009) to increase the production and thus lower the final production costs (Oltra, 2011). The extraction of secondary metabolites with potential applications in biomedicine and pharmacology is a quite new trend in microalgal biotechnology. The natural active compounds present in the microalgal biomass is responsible for distinct biological activities, such as cytotoxic, antibiotic, antioxidant, antifungal, antiinflammatory and antihelminthic compounds (Pulz and Gross, 2004; Gouveia et al., 2008; Plaza et al., 2009 and Patil et al., 2011). The applications of algae are very widespread, including the Biodiesel production, aquaculture feed, and the extraction of nutrients and drugs with higher value (Converti et al., 2009 and Spolaore et al., 2006). Nannochloropsis oculata is a unicellular marine algae belonging to the class Eustigmatophyceae (Durmaz, 2007). N.oculata contains fats, proteins, carbohydrates, chlorophylls, carotenoids, minerals and trace elements (Sukenik et al., 1999). Microalgae are single celled photosynthetic organisms which have relatively simple requirements for growth, which need sunlight to convert water and carbon dioxide $\left(\mathrm{CO}_{2}\right)$ into proteins, amino acids, lipids, polysaccharides, carotenoids and other bioactive compounds (Asha et al., 2011; Mulbry et al., 2008). 
Microalgae are a promising biomass feedstock owing to their faster growth, higher reproduction rate and reduced greenhouse gas emission. Earlier, microalgae have many broad applications in biotechnology (Walter et al., 2005), including biofuels (Chisti, 2007), pharmaceuticals (Lorenz and Cysewski, 2003), aquaculture etc. (Mulbry et al., 2005) Large volume of microalgal biomass cultivated using low cost resources must be carried out to realize the industrial potentials of microalgae. Currently, all methods of producing microalgal biomass for biofuels production and bioproducts are mainly based on suspension culture. Raceway ponds (Chisti, 2007) and photobioreactors (Mata et al., 2010) are commonly used cultivations in large scales. However, open pond production of biomass has proved to be successful only for a limited number of cultures such as Spirulina sp. and Dunaliella sp. which can withstand extreme conditions such as very high salinity or high $\mathrm{pH}$ (Asha et al., 2011).

\section{MICROALGAL METABOLITES}

Microalgae are significant resource for bioactive metabolites, mainly the application as cytotoxic agents in cancer chemotherapy. From the marine microalgae Phaeocystis sp., plenty of antibiotic substances were listed Phaeocystis pouchetii is reported to produce acrylic acid, which constitutes about $7.0 \%$ of the dry weight. The antibiotic substances produced are transferred into food chain as evidences were found in digestive tract of Antartic penguins. Production of $\beta$ carotene and vitamins is vast in halotolerant algae Dunaliella sp. These compounds have much importance for the Mariculture activities (Lipton AP, 2003). Cyanobacteria is well known for isolation of active natural product as it is a most preferable group of organisms. Cyanobacterial strains such as Spirulina, Anabaena, Nostoc and Oscillatoria produce a large variety of secondary metabolites. Blue green algae are known to produce a wide variety of bioactive compounds, which constitutes $40 \%$ lipopeptides, $5.6 \%$ amino acids, $4.2 \%$ fatty acids, $4.2 \%$ macrolides and $9 \%$ amides. The lipopeptides obtained from cyanobacteria includes different compounds like cytotoxic, antitumor, antiviral, antibiotics and the rest activities include antimalarial, antimycotics, multi-drug resistance reversers, anti feedant, herbicides and immunosuppressive agents (Burja et al., 2011); besides the immune effect, blue green algae improves metabolism.

Cyanobacteria are identified to produce antitumor, antiviral, Plant antifungal compounds and they also have cholesterol-lowering effect in animals and humans (Iwata $\mathrm{K}$ et al., 1990). Most of the compounds in cyanobacteria are peptides, including toxins and important candidates for anti-cancer drugs which have a better application in pharmaceutical industries. Peptide synthetases are commonly found in cyanobacteria that are responsible for the production of cyanobacterial hepatotoxins and other peptides.

Among the compounds extracsted from microalgae most of them have antimicrobial, antiviral, anticoagulant antienzymatic, antioxidant, antifungal, anti-inflammatory, and anticancer activity, (Priyadarshani and Rath, 2012, Blunt et al., 2006,Mayer and Hamann, 2005, Plaza et al., 2010, Rodríguez-Meizoso et al., 2008,Carvalho et al., 2013). The Microalgae such as Arthrospira (Spirulina), Botryococcus braunii, Chlorella vulgaris, Dunaliella salina, Haematococcus pluvialis, and Nostoc were used for extraction of bioactive compounds (Table 1), (Palavra et al., 2011, Nobre et al., 2006, Mendes et al., 2006, Michele et al., 2015).

Table 1: Major bioactive metabolites extracted from microalgae.

\begin{tabular}{|c|c|c|}
\hline Microalgae & Bioactive compounds & Reference \\
\hline Spirulina sp. & Polysaccharides & Amaro et al., 2013 \\
\hline Spirulina platensis & $\begin{array}{l}\text { Phycocyanin, C-phycocyanin, Phenolic acids, tocopherols } \\
\text { (vitamin E), neophytadiene, phytol, PUFAs (n-3) fatty acids, } \\
\text { oleic acid, linolenic acid, palmitoleic acid }\end{array}$ & $\begin{array}{l}\text { Iba nez and Cifuentes, 2013; Markou and } \\
\text { Nerantzis, 2013; Singh and dhar, } 2011\end{array}$ \\
\hline Spirulina fusiformis & Diacylglycerols & Singh and dhar, 2011 \\
\hline Haematococcus pluvialis & $\begin{array}{l}\text { Astaxanthin, lutein, zeaxanthin, canthaxanthin, lutein, } \beta \text {-carotene, } \\
\text { oleic acid }\end{array}$ & $\begin{array}{l}\text { Markou and Nerantzis,2013; Plaza, Herrero, } \\
\text { 2009; Markou and. Nerantzis, ] }\end{array}$ \\
\hline Chlorella sp. & $\begin{array}{l}\text { Carotenoids, sulfated polysaccharides, sterols, PUFAs (n-3) fatty } \\
\text { acids }\end{array}$ & Markou and Nerantzis, 2013 \\
\hline Chlorella vulgaris & Canthaxanthin, astaxanthin, peptide, oleic acid & $\begin{array}{l}\text { [Priyadarshani and rath 2012; plaza and } \\
\text { Herrero, 2009, Amaro et al., 2013] }\end{array}$ \\
\hline Chlorella minutissima & Eicosapentaenoic acid (EPA) & [Singh and dhar, 2011] \\
\hline Chlorella ellipsoidea & Zeaxanthin, violaxanthin & Amaro et al., 2013 \\
\hline Dunaliella salina & $\begin{array}{l}\text { trans-Betacarotene, cis-betacarotene, } \beta \text {-carotene, oleic acid, } \\
\text { linolenic acid, palmitic acid }\end{array}$ & $\begin{array}{l}\text { 12, plaza and Herrero, 2009; Singh and } \\
\text { dhar, } 2011\end{array}$ \\
\hline Dunaliella & Diacylglycerols & Singh and dhar, 2011 \\
\hline Botryococcus braunii & Linear alkadienes (C25, C27, C29, and C31), triene (C29) & Jesus, et al., 2013 \\
\hline Chlorella zofingiensis & Astaxanthin & Markou and Nerantzis, 2013 \\
\hline Chlorella protothecoides & Lutein, zeaxanthin, canthaxanthin & $\begin{array}{l}\text { Markou and Nerantzis, 2013; Jesus, et al., } \\
2013\end{array}$ \\
\hline Chlorella pyrenoidosa & Lutein, sulfated polysaccharide & plaza and Herrero, 2009 \\
\hline Nostoc linckia and Nostoc spongiaeforme & Borophycin & Singh and dhar, 2011 \\
\hline Nostoc sp. & Cryptophycin & Singh and dhar, 2011 \\
\hline
\end{tabular}




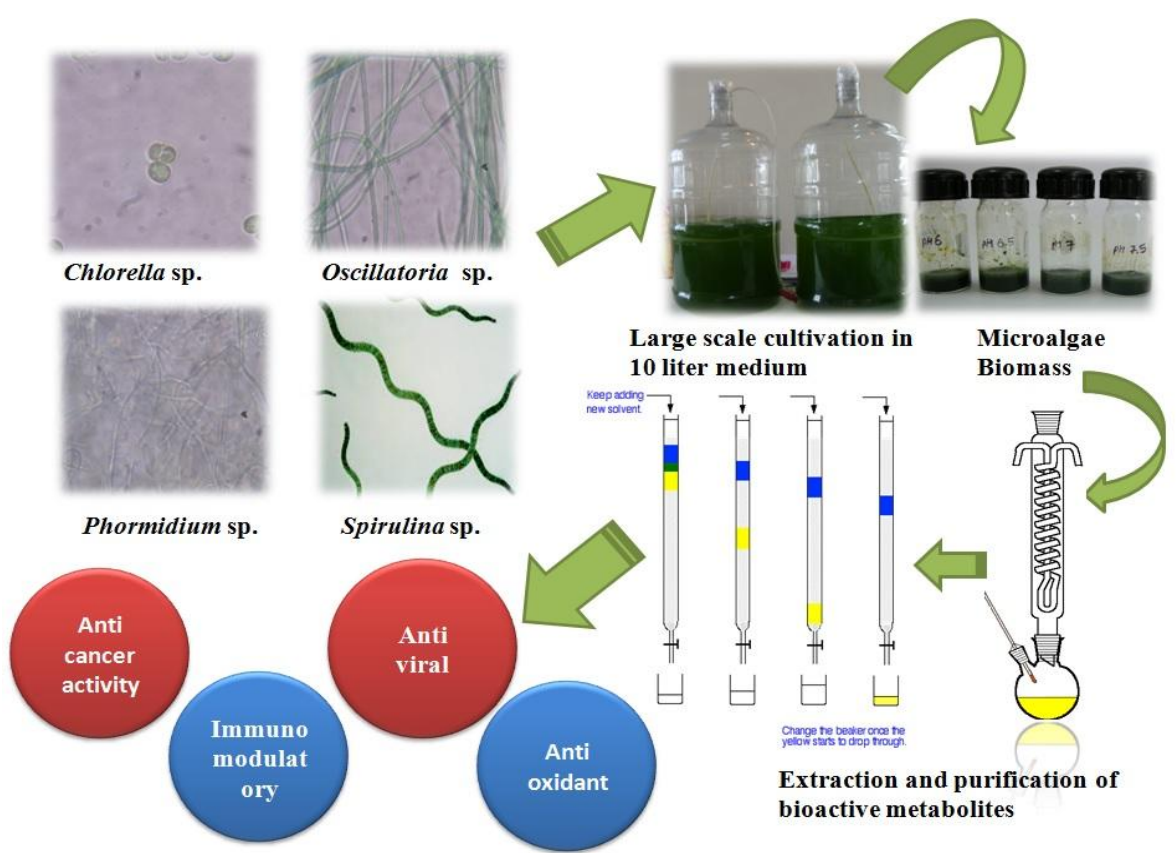

Fig. 1: Biotechnological applications of Bioactive metabolites from Microalgae.

\section{Microalgal metabolites effective against various Diseases}

The bioactive compounds usually secondary metabolites, includes various types of substances ranging from organic acids, carbohydrates, amino acids and peptides, vitamins, growth substances, antibiotics, enzymes to toxic compounds. The metabolites show a wide range of biological activities, including anticancer, antiviral, antioxidant and immunomodulatory effects. (Figure.1) The green alga Dunaliella salina has been mass cultivated in open ponds for the production of $\beta$-carotene. The algae grows in water and is also tolerant to high saline content and is able to produce $\beta$-carotene up to $14 \%$ of its dry weight. (Metting, 1996) Astaxanthin a pigment obtained from microalgae is mainly used a food-colouring agent, natural feed additive for the poultry industry and for aquaculture, particularly as a feed supplement for salmon, trout and shrimp. Recently, astaxanthin has also been sold as a nutraceutical for humans in the form of encapsulated product. In addition, Haematococcus sp. rich in astaxanthin has been marketed as a dietary supplement for human consumption. (Lorenz RT, Cysewski, 2000) The good health benefit of this product is mainly due to its strong antioxidant activity, which is much more higher than $\alpha$-tocopherol (HigueraCiapara et al., 2006). Studies have revealed that astaxanthin has protective effects against various disease such as cancers, inflammatory diseases, metabolic syndrome, diabetes, diabeticnephropathy, neurodegenerative diseases and eye diseases (Yuan et al., 2011).

\section{Microalgae as source of Bioactive compounds Spirulina}

Some of the microalgae have been consumed as food due to their high nutritional value. For example, Spirulina has been harvested for food by the natives in Mexico and Chad (Africa) since ancient times (Barsanti and Gualtieri, 2006). In Chad, Spirulina is regularly harvested from the alkaline lake Kossorom for dry cake known as 'dihe'. In the present day, spirulina still contributes to the economy of Chad as the local trading value of 'dihe' is worth more than US\$100,000 (Abdulqader et al., 2000) Spirulina is being cultured in open ponds in countries such as Thailand, China, United States and India for the commercial production of the biomass to use them as dietary supplement in countries. The estimated amount of annual worldwide production of Spirulina ranges from 3000 to 4000 metric tons (Belay et al., 2008). Spriulina is regarded as a nutritious food mainly due to high protein content. Apart from being consumed as a food product, Spirulina have therapeutic implications, including the health problems such as diabetes, arthritis, anaemia, cardiovascular diseases and cancer. (Mani et al.,2008) Spirulina is also useful nutritional enhancer as it is incorporated into various food products for therapeutic administration of some diseases such as chronic disorders such as diabetes, hypertension and heart. (Iyer et al., 2008) Spirulina is well-known for its antioxidant activity and its compounds such as phycocyanin and vitamin E. (Chu 2011: Chu et al., 2010) Another cyanobacterium named nostoc has been consumed as food since 2,000 years ago. (Han et al., 2004) The algae is regarded as a healthy food as it is rich in protein and pigment contents, and is also has low fat content.

\section{Chlorella}

Chlorella is abundantly found microalgae which has been mass cultured for production of health food in the form of pills and powder. The mass culture of Chlorella was first pilot tested in Boston, USA, and this was continued by other cultivation plants in Israel, Japan and Czechoslavakia. (Iwamoto, 2004) The first commercial production plant of Chlorella was established in Japan 
in 1961 by Nihon Chlorella Inc. Following him, chlorella factories were constructed in different countries such as Taiwan, Malaysia and Indonesia. By 1980, nearly Forty six large-scale plants were established in Asia which had a higher production of $1000 \mathrm{~kg}$ Chlorella biomass per month (Spolaore et al., 2006). However, the plant in Malaysia was withdrawen in the early 70's. At present Chlorella products are marketed in Malaysia and are mainly imported from Japan and Taiwan.

\section{Cyanobacteria and dinoflagellates}

Toxic metabolites produced by microalgae (phycotoxins) are considered to be a promising group of bioactive molecules. These compounds are produced mainly by dinoflagellates and cyanobacteria, mainly those that cause harmful algal blooms in either marine or freshwater environments. Excessive growth of dinoflagellates may lead to discolouration of the sea, forming red tides whereas blooms of cyanobacteria in lakes declines the excessive nutrients. Nearly about 300 species of microalgae have been reported to form algae blooms, among them one fourth of these species are toxin producers (Hallegraef et al., 2003). These toxins can lead to health hazard in humans, domestic animals and wildlife with toxic effects including neurotoxicity, hepatoxicity, cytotoxicity and dermatoxicity (Carmichael, 2001). Phycotoxins demonstrate a wide range of biological activities such as cytotoxic, antitumor, antibiotic, antifungal, immunosuppressant and neurotoxic activities, which present a great potential for biotechnological use (Garcia-Camacho et al., 2007). Many patents related to toxins have been filed. As most of the algal toxins are neurotoxic compounds, they are suitable as tools used to explore brain works and for investigations on neurodegenerative diseases. For example, okadaic acid from Dinophysis used in the treatment of cognitive impairment and schizophrenia is a potent neurotoxin used in the studies on the therapeutic effects of a typical antipsychotic drugs (He et al., 2005). Whereas, pectentoxins from Dinophysis had showed cytotoxic activity against several human cancer cell lines (Jung et al., 1995).

\section{Antiviral activity of Microalgal compounds}

Microalgae are a potential sources of antiviral compounds as they are yet to be fully explored. For instance, from 600 cultures of cyanobacteria, screening of extracts showed a hit rate of $10 \%$ in inhibiting cellular infection of HIV-1, HSV-2, and antirespiratory syncytia virus. (Patterson et al., 1993) A novel compound named cyanovirin-N from cyanobacteria, has been proven to be a potent virucidal agent against HIV, by blocking the interaction of the viral glycoprotein gp120 with CD4 (Dey et al., 2000). There is latent of developing a relevant vaginal microbicide against HIV based on this compound (Tsai et al., 2004). The sulfated polysaccharide derived from Spirulina platensis had shown antiviral activity by hindering the entry of enveloped viruses such as Human cytomegalo viruses, Herpes simplex, and measles virus into the cell (Hayashi et al., 1996: Ayehunie et al., 1998). Sulfated polysaccharide extracted from the red alga
Porphyridium has also shown better antiviral activities by preventing the adsorption of the virions against HSV-1, HSV-2 and Varicella zoster virus (Huleihel et al., 2001).

\section{Anticancer activity of Microalgal compounds}

Bioactive molecules showing anticancer activities are one of the targeted compounds from microalgae. On screening of about 1,000 extracts of cyanobacteria isolated from various surroundings for antineoplastic activity (Patterson et al., 1991). Antineoplastic activity was totally based on the inhibitory effects on the differentiation of human leukaemic cells, and a $7 \%$ hit rate was reported. In a further screening, 501 extracts from marine microalgae were assessed using mechanism based assays, including activities against three enzymes protein kinase $\mathrm{C}$, protein tyrosine kinase and inosine monophosphate dehydrogenase (Gerwick et al., 1994). A novel chlorosulfolipid isolated from Poteriochromonas malhamensis shown inhibition of protein tyrosine kinase activity. Marine cyanobacteria that are potential producers of bioactive compounds and effective in destroying cancer cells by inducing apoptotic death, or affecting cell signaling by activation of protein kinase $\mathrm{C}$ family signaling enzymes (Boopathy, 2010).

A variety of mammalian cells including the epidermoid carcinoma cells have been inhibited by polyketide-derived macrolides scytophycins which was isolated from Scytonema pseudohofmanni (Ishibashi et al., 1986). The compounds are more active against intraperitoneally implanted lymphocytic leukaemia and lung carcinoma (Furusawa, et al., 1994). Another metabolite extracted from Nostoc ATCC 53789, cryptophycin is a effective anticancer compound (Schwartz et al., 1990) whereas a protein serine inhibitor named scytonemin isolated from Stigonema which may provide an admirable drug with antiproliferative and antiinflammatory activities (Stevenson et al., 2002).

\section{Microalgal application in Environment}

The immobilized Chlorella vulgaris in alginate was found to be efficient in removing colour from textile dyes (Chu at al., 2009). Chlorella vulgaris and Scenedesmus obliquus were immobilized and have shown to be effective in removing phosphorus and nitrogen from urban wastewater operated on a semicontinuous mode (Ruiz-Marin et al., 2010). In another reseach, co-immobilisation of microalgae and bacteria have proven to be more effective in removing nutrients such as nitrate, ammonium and phosphate from wastewater rather than immobilised microalgae without bacteria (De-Bashan et al., 2002). While microalgae which are tolerant to toxicants are useful in bioremediation, on the other hand sensitive species are useful tools for bioassaying and biomonitoring of pollutants in the environment (Ismail, 2004). Microalgae are used in bioassay of organisms to analyze the toxicity of harmful pollutants such as heavy metals, pesticides and pharmaceuticals. Heavy metals have been detected vastly in the aquatic ecosystems and even in marine ecosystems such as fish and mussel (Irwandi and Farida, 2009). 


\section{CONCLUSION}

The aim of this paper is to review on the microalgal metabolites, the source for bioactive compounds present in different microalgae. This paper also deals with the ability of microalgae to produce bioactive compounds that makes it an important tool in various sectors of biotechnology. Microalgae have long been used as nutritional supplement or food and feed sources. Many of the pharmaceutically interesting compounds in cyanobacteria are peptides, including cyanobacterial toxins and important candidates for anti-cancer drugs. A clear picture on the ability of microalgal bioactive compounds to tackle various diseases has been put forth in this paper. The cultivation of microalgae is known to be the most profitable in the biotechnological industry.

\section{REFERENCES}

Abdulqader G, Barsanti L, Tredici MR. Harvest of Arthrospira platensis from Lake Kossorom (Chad) and its household usage among the Kanembu. J Appl Phycol 2000; 12: 493-498.

Amaro HM, Barros R, Guedes AC, Sousa-Pinto I, Malcata FX. Microalgal compoundsmodulate carcinogenesis in the gastrointestinal tract. Trends in Biotechnology, 2013; 31(2): 92-98.

Asha P, Nira KS, Ashok P, Edgard G, Datta M. Cyanobacteria and microalgae: a positive prospect for biofuels. Bioresour. Technololgy , 2011; 102: 10163-10172.

Ayehunie S, Belay A, Baba TW, Ruprecht RM. Inhibition of HIV- 1 replication by an aqueous extract of Spirulina platensis. J Aquir Immun Defic Syndr Hum Retrovirol, 1998; 18: 7-12.

Barsanti L, Gualtieri P. Algae: anatomy, biochemistry and biotechnology. Florida: Taylors R Francis Group, 2006; 301.

Belay A. Spirulina (Arthrospira): production and quality assurance. In: Gershwin ME, Belay A, eds. Spirulina in human nutrition and health. Boca Raton: CRC Press, 2008; 1-25.

Blunt W, Bl. Copp, M. H. G. Munro, P. T. Northcote, and M. R. Prinsep, "Marine natural products.Natural Product Reports,2006; 23:1426-78.

Boopathy NS, Kathiresan K. Anticancer drugs from marine flora; an overview. J Oncol, 2010; Article ID 214186: 18

Brennan L and Owened PAuthor Vitae Biofuels from microalgae A review of technologies for production, processing and extractions of biofuels and co-products. Renewable and Sustainable Energy Reviews, 2010; 14(2):557-577.

Burja AM, Banaigs B, Abou-Mansour E, Burgess JG and Wright PC Marine cyanobacteria - a prolific source of natural products. Tetrahedron, 2001; 57:9347-9377.

Carmichael WW. Health effects of toxin-producing cyanobacteria: the CyanoHabs. Hum Ecol Risk Assess, 2001;7:1393-1407.

Chisti, Y. Biodiesel from microaglae. Biotechnology. Advances, 2007; 25: 294-396.

Chu WL, Lim YW, Radhakrishnan AK, Lim PE. Protective effect of aqueous extract from Spirulina platensis against cell death induced by free radicals. BMC Complement Altern Med 2010; 10: 53

Chu WL, See TC, Phang SM. Use of immobilised Chlorella vulgaris for the removal of colour from textile dyes. J Appl Phycol, 2009; 21: 641-648

Chu WL. Potential applications of antioxidant compounds from algae. Curr Top Nutraceut Res 2011; 9: 83-98. 13.

Converti A, Casazza AA, Ortiz EY, Perego P, Borghi MD. Effect of temperature and nitrogen concentration on the growth and lipid content of Nannochloropsis oculata and Chlorella vulgaris for biodiesel production, Chemical Engineering and Processing: Process Intensification, 2009; 48: 1146-1151
De Jesus Raposo MF, De Morais RMSC, and Morais AMMB. Health applications of bioactive compounds from marine microalgae.Life Sciences, 2013; 93(15):479-486.

De-Bashan, LE, Moreno M, Hernández JP, Bashan Y. Removal of ammonium and phosphorus ions from synthetic wastewater by the microalgae Chlorella vulgaris coimmobilized in alginate beads with the microalgae growth-promoting bacterium Azospirillum brasiliense. Water Res 2002; 36: 2941-2948.

Demirbas A. Use of algae as biofuel sources. Energ Convers Manage, 2010; 51:2738-2749.

Dey B, Lerner DL, Lusso P, Boyd MR, Elder JH, Bergeri EA. Multiple antiviral activities of cyanovirin-N: blocking of human immunodeficiency virus Type 1 gp120 interaction with CD4 and coreceptor and inhibition of diverse enveloped viruses. J Virol, 2000; 74: 4562-4569

Durmaz Y. Vitamin E (tocopherol) production by the marine microalgae Nannochloropsis oculata (Eustigmatophyceae) in nitrogen limitation, Aquaculture, 2007; 272:717-722.

Furusawa E, Moore RE, Mynderse JS, Norton TR, Patterson GML. New purified culture of Scytonema pseudohofmanni ATCC 53141 is used to produce scytophycins $\mathrm{A}, \mathrm{B}, \mathrm{C}, \mathrm{D}$ and $\mathrm{E}$, which are potent cytotoxins and antineoplastic agents, USA Patent Number 5281533, 1994;

Garcia-Camacho F, Gallardo-Rodriquez J, Sanchez-Miron A, CeronGracia MC, Belarbi EH, Chisti Y, Molina-Grima E Biotechnological significance of toxic marine dinoflagellates. Biotechnol Adv, 2007; 25: 176-194

Gerwick WH, Roberts MA, Proteau PJ, Chen JL. Screening cultured marine microalgae for anticancer type activity. J Appl Phycol, 1994; 6: 143-149.

Gouveia L, Batista AP, Sousa I, Raymundo A, Bandarra NM. Microalgae in novel food products. In Food Chemistry Research Developments. Edited by: Papadopoulos KN. Hauppauge, NY: Nova Science Publishers, Inc., 2008;1-37.

Hallegraef GM. Harmful algal blooms: a global overview. In: Hallegraef GM, Andersen DM, Cembella AD, eds. Manual on harmful marine microalgae. Paris: UNESCO Publishing, 2003; 25-49.

Han D, Bi Y, Hu Z. Industrial production of microalgal cellmass and secondary products - species of high potential. Nostoc. In Richmond A, ed. Handbook of microalgal culture: biotechnology and applied phycology. Oxford: Blackwell Science, 2004; 304-311.

Hayashi K, Hayashi T, Kojima I. A natural sulfated polysaccharide, calcium spirulan, isolated from Spirulina platensis in vitro and ex vivo evaluation of anti-herpes simplex virus and anti-human immunodeficiency virus activities. AIDS Res Hum Retrovir, 1996; 12: 1463-1471.

He J, Yang Y, Xu HY, Zhang X, Li XM. Olanzapine attenuates the okadaic acid-induced spatial memory impairment and hippocampus cell death in rats. Neuropsychopharmacology, 2005; 30: 1511-1520.

Higuera-Ciapara I, Felix-Valenzuela L, Goycoolea FM. Astaxanthin: a review of its chemistry and applications. Crit Rev Food Sci Nutr, 2006, 46: 185-196.

Huleihel M, Ishamu V, Tal J, Arad SM. Antiviral effect of red microalgal polysaccharides on Herpes simplex and Varicella zoster viruses. J Appl Phycol, 2001; 13: 127-134.

Iba nez E and Cifuentes A. Benefits of using algae as natural sources of functional ingredients.Journal of the Science of Food and Agriculture,2013; 93(4):703-709.

Irwandi J, Farida O. Mineral and heavy metal contents of marine fin fish in Langkawi Island, Malaysia. Int Food Res J, 2009; 16: 105-112.

Ishibashi M, Moore RE, Patterson GML, Xu C, Clardy J. Scytophycins, cytotoxic and antimycotic agents from the cyanophyte Scytonema pseudohofmanni. J Org Chem,1986; 51: 5300-5306.

Ismail M. Phytoplankton and heavy metal contamination in the marine environment. In: Phang SM, Brown M, eds. Biomonitoring in tropical coastal ecosystems, Kuala Lumpur: University of Malaya Maritime Research Centre (UMMrec), 2004; 15-96.

Iwamoto $\mathrm{H}$. Industrial production of microalgal cell-mass and secondary products - major industrial species. Chlorella. In: Richmond A, 
ed. Handbook of microalgal culture: biotechnology and applied phycology. UK: Blackwell Science, 2004; 255-263.

Iwata K, Inayama $\mathrm{T}$ and Katoh T. Effect of Spirulina platensis on plasma lipoprotein lipase activity in fructose induced hyperlipidemia in rats. J. Nutr. Sci. Vitaminol, 1990; 36:165-171

Iyer UM, Dhruv SA, Mani IU. Spirulina and its therapeutic implications as a food product. In: Gershwin ME, Belay A, eds. Spirulina in human nutrition and health. Boca Raton: CRC Press, 2008; 51-70.

Jung JH, Sim CS, Lee CO. Cytotoxic compounds from the twosponge association. J Nat Prod, 1995; 58: 1722-1726.

Kobayashi J, ShimboK, Kubota T, Tsuda M. Bioactive macrolides and polyketides from marine dinoflagellates. Pure Appl Chem, 2003; 75: 337-342.

Lipton AP. Marine bioactive compounds and their application in mariculture. Marine Ecosystem, Univ. of Kerala, Kariavattom,2003; 2(4): 695-581.

Lorenz RT, Cysewski GR. Commercial potential for Haematococcus microalgae as a natural source of astaxanthin. Trends Biotechnol, 2000; 18: 160-167.

Mani UV, Iyer UM, Dhruv SA, Mani IU, Sharma KS. Therapeutic utility of Spirulina. In: Gershwin ME, Belay A, eds. Spirulina in human nutrition and health. Boca Raton: CRC Press, 2008; 71-99.

Markou $G$ and Nerantzis E. Microalgae for high-value compounds and biofuels production: a review with focus on cultivation under stress conditions. Biotechnology Advances, 2013, 31:8,1532-1542.

Mata TM, Martins AA, Caetano NS. Microalgae for biodiesel production and other applications: a review. Renew. Sust. Energy Res., 2010; 14: 217-232.

Mayer MS and Hamann MT, "Marine pharmacology in 20012002: marine compounds with anthelmintic, antibacterial, anticoagulant, antidiabetic, antifungal, anti-inflammatory, antimalarial, antiplatelet, antiprotozoal, antituberculosis, and antiviral activities; affecting the cardiovascular, immune and nervous systems and other miscellaneous mechanisms of action," Comparative Biochemistry and Physiology Part C: Toxicology \& Pharmacology, 2004;140:3:265-286,

Mendes, AD. and A F Palavra, "Supercritical $\mathrm{CO}_{2}$ extraction of $\gamma$-linolenic acid and other lipids from Arthrospira (Spirulina)maxima: comparison with organic solvent extraction," Food Chemistry,2006; 99(1) :57-63,

Metting FB. Biodiversity and application of microalgae. J Ind Microbiol, 1996; 17: 477-489.

Michele Greque deMorais, Bruna da SilvaVaz, Etiele Greque de Morais, and Jorge Alberto Vieira Costa. Biologically Active Metabolites Synthesized by Microalgae. BioMed Research International, 2015; 7-15.

Mulbry W, Kondrad S, Buyer J .Treatment of dairy and swine manure effluents using freshwater algae: fatty acid content and composition of algal biomass at different manure loading rates. J. Appl. Phycol., 2008; 20: 1079-1085.

Mulbry W, Westhead EK, Pizarro C, Sikora L. Recycling of manure nutrients: use of algal biomass from dairy manure treatment as a slow release fertilizer. Bioresource Technology, 2005; 96: 451-458.

Nobre F, Marcelo R. Passos. Supercritical carbon dioxide extraction of astaxanthin and other carotenoids from the microalga Haematococcus pluvialis. European Food Research and Technology,2006; 223(6): 787-790.

Oltra C. Stakeholder perceptions of biofuels from microalgae. Energy Policy, 2011; 39:1774-1781.

Palavra AMF, Coelho JP, Barroso JG. Supercritical carbon dioxide extraction of bioactive compounds from microalgae and volatile oils from aromatic plants, Journal of Supercritical Fluids, 2011; 60: 21-27.

Patil KJ, Patil VA, Mahajan SR, Mahajan RT. Bio-activity of algae belonging to Bhusawal region, Maharashtra. Curr Bot, 2011,2:29-31.

Patterson GML, Baker KK, Baldwin CL, Bolis CM, Caplan FR, Larsen LK, et al. Antiviral activity of cultured blue-green algae (Cyanophyta). J Phycol, 1993;29: 125-130.
Patterson GML, Baldwin CL, Bolis CM, Caplan FR, Karuso H, Furusawa $\mathrm{E}$ et al. Antineoplastic activity of cultured blue-green algae (Cyanobacteria). J Phycol, 1991; 27: 530-536.

Pienkos P, Darzins A. The promise and challenges of microalgal derived biofuels. Biofuel Bioprod Bior, 2009; 3:431-440.

Plaza M, Herrero M, Cifuentes A, Ibáñez E. Innovative natural functional ingredients from microalgae. J Agric Food Chem, 2009; 57:7159-7170

Plaza M, Santoyo S, Jaime L. Screening for bioactive compounds from algae. Journal of Pharmaceutical and Biomedical Analysis,2010; 51,2, 450-455.

Priyadarshani I and Rath B, Commercial and industrial applications of micro algae - a review, Journal of Algal Biomass Utilization, 2012; 3:4, 89-100

Pulz O, Gross W. Valuable products from biotechnology of microalgae. Appl Microbiol Biotechnol, 2004: 65:635-648.

R. Carvalho, A. Costa-Neves, G. A. A. Conserva "Biologically active compounds from cyano bacteria extracts: in vivo and in vitro aspects," Brazilian Journal of Pharmacognosy,2013; 23(3):471-480, 2013.

Richmond A. Handbook of microalgal culture: biotechnology and applied phycology. Blackwell Science Ltd, 2004.

Rodríguez-Meizoso L. Jaime S. Santoyo "Pressurized fluid extraction of bioactive compounds from Phormidium species," Journal of Agricultural and Food Chemistry 2008; 56, 10, 3517-3523.

Ruiz-Marin A, Mendoza-Espinosa L, Stephenson T. Growth and nutrient removal in free and immobilized green algae in batch and semi-continuous cultures treating real wastewater. Bioresource Technology, 2010; 101: 58-64.

Schwartz RE, Hirsch CF, Sesin DF, Flor JE, Chartrain M, Fromtling RE. Pharmaceuticals from cultured algae. J Ind Microbiol,1990; 5: $13-123$

Singh NK and Dhar DW. Microalgae as second generation biofuel. A review.Agronomy for Sustainable Development, 2011; 31(4):605-629.

Spolaore P, Joannis-Cassan C, Duran E, Isambert A Commercial applications of microalgae. J Biosci Bioengrg, 2006; 101: 87 96.

Stevenson CS, Capper EA, Roshak AK, Marquez B, Echman C, Jackson JR, Mattern M. The identification and characterization of the marine natural product scytonemin as a novel antiproliferative pharmacophore. J Pharmacol Exp Ther, 2002; 303: 858-866.

Sukenik A, Cohen Z, in: Cohen Z (Ed.), Chemicals from Microalgae, Taylor \& Francis; 1999 (Chapter 3).

Tsai CC, Emau P, Jiang Y, Agy MB, Shattock RJ, Schmidt A et al. Cyanovirin-N inhibits AIDS virus infections in vaginal transmission models. AIDS Res Human Retrovir, 2004; 20: 11-18.

Walker TL, Purton S, Becker DK. Collet C: Microalgae as bioreactors. Plant Cell Rep, 2005; 24:629-641.

Wijffels RH, Barbosa MJ. An outlook on microalgal biofuels. Science, 2010; 329:796-799.

Yuan JP, Peng J, Yin K, Wang JH. Potential health-promoting effects of astaxanthin: a high-value carotenoid mostly from microalgae. Mol Nutr Food Res, 2011; 55: 150-165.

How to cite this article:

Santhosh S, Dhandapani R, Hemalatha N. A Review on Potential Biotechnological applications of Microalgae. J App Pharm Sci, 2016; 6 (08): 179-184 